\title{
Analisis Pemanfaatan Zat Aditif pada Reclaimed Asphalt Pavement untuk Lapisan Beton Aspal
}

\author{
Additive Utilization Analysis in Reclaimed Asphalt Pavement for \\ Asphalt Concrete Layer
}

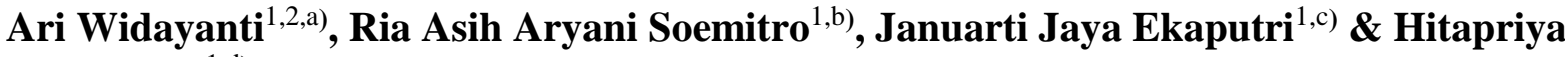 \\ Suprayitno ${ }^{1, \mathrm{~d})}$ \\ ${ }^{1)}$ Departemen Teknik Sipil, Institut Teknologi Sepuluh Nopember Surabaya. \\ ${ }^{2)}$ Jurusan Teknik Sipil, Universitas Negeri Surabaya.
}

Koresponden : ${ }^{a)}$ ariwidayanti@unesa.ac.id, ${ }^{b)}$ ria@ce.its.ac.id, ${ }^{c}$ januarti@ce.its.ac.id \&

${ }^{d)}$ hitapriya@ce.its.ac.id

\begin{abstract}
ABSTRAK
Infrastruktur dan fasilitas transportasi merupakan hal-hal yang sangat diperlukan untuk menunjang aktivitas masyarakat, pembangunan dan pengembangan wilayah. Manajemen aset infrastruktur dan fasilitas transportasi perlu dikelola dengan baik. Dalam rangka penghematan sumberdaya alam, maka pemanfaatan RAP sebagai hasil pengerukan sebagian perkerasan jalan sangat diperlukan. RAP merupakan material sisa, sehingga terdapat kelemahan yang dapat mempengaruhi kinerja teknisnya. Oleh karena itu memerlukan penambahan material lain untuk dapat memperbaiki sifat material RAP. Penambahan zat aditif mampu memperbaiki sifat RAP terutama dari sisi kelemahan aspal RAP pada lapisan aspal beton. Tujuan studi ini adalah memperoleh hasil analisis terhadap sifat fisik dan kimia zat aditif untuk memperbaharui sifat aspal RAP pada lapisan aspal beton. Metode yang digunakan adalah studi literatur dari peneliti terdahulu dan analisis zat aditif terhadap parameter pengujian aspal. Hasil yang diperoleh adalah pemanfaatan zat aditif berpengaruh terhadap nilai penetrasi, daktilitas, viskositas aspal. Penambahan zat aditif pada RAP dapat meningkatkan nilai penetrasi aspal RAP dan mengurangi viskositas, sehingga mengurangi getas pada aspal RAP dan meningkatkan kinerja campuran aspal beton. Zat aditif NR aman dan layak digunakan untuk aditif pada perkerasan jalan dengan RAP.
\end{abstract}

Kata Kunci: manajemen aset infrastruktur, perkerasan jalan, zat aditif, RAP.

\section{PENDAHULUAN}

Infrastruktur dan fasilitas transportasi merupakan hal-hal yang sangat diperlukan untuk menunjang aktivitas masyarakat, pembangunan dan pengembangan wilayah. Manajemen aset infrastruktur dan fasilitas transportasi perlu dikelola dengan baik, sehingga dapat berfungsi dan memberikan pelayanan secara maksimal serta sesuai dengan peruntukannya (Suprayitno \& Suprayitno, 2018; Widayanti dkk, 2018a).

Dalam rangka penghematan sumberdaya alam terutama agregat dan aspal, maka pemanfaatan RAP yang bertumpuk-tumpuk sebagai hasil pengerukan sebagian perkerasan jalan sangat diperlukan. Reclaimed Asphalt Pavement (RAP) merupakan material hasil pengerukan lapisan perkerasan jalan dengan alat Cold Milling Machine. Pemanfaatan material RAP mempunyai kendala karena sifat dari aspal RAP yang mempunyai kelemahan dalam beberapa aspek fisik. RAP merupakan material sisa, sehingga terdapat kelemahan yang dapat mempengaruhi kinerja teknisnya, apabila dimanfaatkan secara langsung untuk perkerasan jalan. 
Oleh karena itu, pemanfaatan RAP memerlukan penambahan material lain sehingga dapat memperbaiki kelemahan yang ada. Penambahan zat aditif merupakan salah satu upaya untuk memperbaiki sifat RAP terutama dari kelemahan aspal RAP untuk lapisan aspal beton.

Proses ekstraksi merupakan proses yang dilakukan untuk memisahkan agregat RAP dari aspal RAP. Dari proses ini dapat diperoleh persentase aspal yang terkandung pada RAP, dan dari hasil analisis saringan dapat diperoleh ukuran fraksi agregat RAP. Recovery RAP merupakan proses pemisahan aspal RAP dengan zat pembentuknya.

Salah satu sifat campuran perkerasan jalan dengan RAP adalah keras dan getas. Hal ini disebabkan oleh keberadaan material yang sudah lama terhampar pada permukaan jalan dan aspal mengalami penuaan. Penuaan ini disebabkan oleh adanya muatan/beban kendaraan, kondisi lingkungan, temperatur, panas matahari, curah hujan yang merupakan kondisi iklim dan beban pada umumnya jalan di Indonesia. Sifat aspal akan berubah seiring dengan panas dan umur aspal (Sukirman, 1995).

Pentingnya zat aditif untuk RAP adalah untuk memperbaiki sifat fisik aspal RAP yang sudah mengalami penuaan. Penuaan pada aspal diakibatkan oleh adanya pengaruh beban muatan kendaraan, oksidasi aspal, temperatur panas, hujan, iklim dan kondisi drainase pada permukaan perkerasan jalan (Sukirman, 2003).

Pengaruh zat aditif terhadap lapisan Asphalt Concrete yaitu dapat meningkatkan penetrasi, menurunkan viskositas sehingga mengurangi getas pada campuran perkerasan jalan. Hal ini diharapkan dapat meningkatkan kinerja campuran aspal beton.

Dalam hal pemanfaatan RAP sebagai bahan perkerasan jalan yang lebih efisien lagi, maka diperlukan studi tentang analisis penambahan zat aditif terhadap kinerja campuran perkerasan jalan. Analisis terhadap zat aditif mencakup sifat fisik dan kimiawi dari zat aditif yang berfungsi untuk memperbaharui aspal dari RAP yang sudah mengalami penuaan akibat perubahan temperatur, iklim, oksidasi dan pembebanan lalu lintas.

\section{STUDI PUSTAKA}

\section{Asphalt Concrete/Beton Aspal}

Asphalt Concrete/Beton Aspal adalah jenis perkerasan jalan yang merupakan campuran antara agregat dan aspal, dengan atau tanpa bahan tambahan. Tujuh karakteristik campuran beton aspal yang diharapkan meliputi stability/stabilitas, durability/keawetan, flexibility /kelenturan, fatigue resistance/ketahanan terhadap kelelahan, skid resistance/ketahanan geser atau kekesatan permukaan, impermeable/kedap air, workability/kemudahan pelaksanaan (Sukirman, 2003).

\section{Aspal}

Aspal adalah material perekat/cementitious, berwarna hitam atau coklat tua. Aspal dapat diperoleh di alam (aspal alam), atau berupa residu hasil pengilangan minyak bumi (aspal minyak). Aspal mengandung senyawa hidrokarbon, nitrogen dan logam lainnya. Mutu kimia aspal ditentukan berdasarkan komponen pembentuknya. Kisaran besaran aspal adalah 4-10\% berdasarkan berat campuran, dan 10-15\% berdasarkan volume campuran (Sukirman, 2003).

Aspal minyak digunakan untuk konstruksi jalan raya, bersifat mengikat agregat, memberikan lapisan kedap air, tahan terhadap pengaruh asam, basa dan garam. Jika lapisan perkerasan dibuat dengan aspal yang bermutu baik, maka akan tahan terhadap pengaruh cuaca dan reaksi kimia, serta memberikan lapisan kedap air. Sifat aspal akan berubah dipengaruhi oleh panas dan umur. Aspal menjadi kaku dan rapuh, daya adesi terhadap partikel agregat akan berkurang. Oleh karena itu diperlukan upaya untuk menganalisis lebih lanjut terhadap sifat aspal dan proses pelaksanaan di lapangan (Sukirman, 1995).

Komposisi kimia aspal terdiri dari asphaltenes dan maltenes. Asphaltenes tidak larut dalam n-heptane, terdiri dari senyawa hidrokarbon, berwarna hitam atau coklat tua. Maltenes 
larut dalam n-heptane, terdiri dari resins dan oil, berupa cairan kental, mudah berubah sesuai dengan perubahan temperatur dan masa pelayanan jalan. Resins berupa cairan berwarna kuning atau coklat tua, sedangkan oils berwarna lebih muda. Resins menghasilkan sifat adhesi aspal, mudah hilang atau berkurang selama masa pelayanan jalan (Sukirman, 2003).

Durabilitas aspal merupakan fungsi ketahanan aspal terhadap perubahan kimia selama proses pencampuran, masa pelayanan, proses pengerasan seiring waktu. Proses pengerasan aspal disebabkan oleh adanya oksidasi, penguapan dan perubahan kimia. Reaksi kimia dapat mengubah resins menjadi asphaltenes, dan oils menjadi resins, yang mengakibatkan peningkatan viskositas aspal (Sukirman, 2003).

\section{Reclaimed Asphalt Pavement}

Reclaimed Asphalt Pavement adalah material hasil pengerukan lapisan perkerasan jalan dengan alat Cold Milling Machine dengan cara Milling atau full depth removal (TRB, 2011). Reclaimed Asphalt Pavement (RAP) dan/atau Reclaimed Aggregate Material (RAM) diperoleh dari lapisan perkerasan yang kemudian didaurulang pada fasilitas Hot Mix Asphalt Plant (Roberts dkk, 1996).

Proses daur ulang perlu dilakukan dengan banyak pertimbangan. Beberapa lapisan perkerasan yang sudah lama perlu untuk dikeruk dan digantikan dengan material baru. Daur ulang perkerasan jalan merupakan salah satu strategi pada konservasi energi dan material yang diperlukan pada saat ini dan masa mendatang. Banyak pihak yang mengizinkan kontraktor untuk mengganti HMA (Hot Mix Asphalt) daur ulang sebagai pengganti HMA asli karena keduanya mempunyai kualitas dan kekuatan struktural yang sama. Beberapa pihak tidak memperbolehkan HMA daur ulang digunakan pada lapisan permukaan terutama karena kurangnya data kinerja untuk lapisan permukaan (Roberts dkk, 1996).

\section{Zat Aditif}

Zat aditif merupakan material yang ditambahkan pada campuran. Kelebihan zat aditif adalah dapat memperbaiki sifat aspal dalam hal meningkatkan penetrasi, daktilitas, dan menurunkan viskositas. Kelemahannya yaitu keberadaannya yang masih jarang digunakan di Indonesia sehingga harus mengimpor dari luar negeri seperti USA, Jepang. Oleh karena itu perlu dikembangkan material lain sebagai pengganti zat aditif yang merupakan material impor, sehingga dapat ditemukan alternatif lain berdasarkan material lokal. Efek terhadap penghematan bahan aspal yaitu mengurangi persentase aspal yang digunakan dalam kisaran 20\% dalam persentase berat aspal (Handayani, 2016).

Pemanfaatan RAP memerlukan propertis RAP meliputi kadar aspal dalam RAP (TRB, 2011). Kadar aspal dalam RAP berdasarkan persyaratan daur ulang aspal dalam RAP hasil ekstraksi dan recovery menurut SNI 8279: 2016 adalah minimal 3,8\%. Penetrasi pada $25^{\circ} \mathrm{C}$, 100 g, 5 detik, 0,1 mm menurut SNI 2456: 2011 adalah minimal 5\% (Pusjatan, 2018 dalam Nono, 2018).

Proses ekstraksi merupakan proses pemisahan agregat dan aspal dalam RAP dengan menggunakan alat Extractor Solvent. Proses ini menghasilkan kadar aspal dalam RAP dan agregat RAP. Proses recovery RAP adalah proses pemisahan aspal dengan zat pembentuknya.

RAP yang akan digunakan untuk lapisan perkerasan jalan harus diketahui dari sumber asalnya dan bergantung pada sifat material pembentuknya, syarat untuk pemakaiannya sehingga dapat diperoleh bahan peremaja yang cocok digunakan untuk mengantisipasi kelemahan dari sifat material pembentuk RAP (Nono, 2017). 
Tabel 1. Batasan Sifat Aspal RAP untuk Daur Ulang dari Berbagai Negara

\begin{tabular}{|c|c|c|}
\hline Negara & Titik Lembek $\left(\mathbf{~}^{\mathbf{0}} \mathbf{)}\right.$ & Penetrasi (dmm) \\
\hline Belgia & - & $>10$ \\
\hline Inggris & - & $>15$ \\
\hline Jerman, Irlandia, Polandia, Portugal & $<70$ & $>15$ \\
\hline Perancis & $<77$ & $>5$ \\
\hline Slowakia & $<70$ & - \\
\hline Sumber: Nono, 2017 & & \\
\hline
\end{tabular}

Bahan peremaja atau Rejuvenil/Aditif adalah bahan peremaja untuk aspal hasil RAP. Zat aditif mengandung senyawa aromatik ringan, yang berfungsi untuk menggantikan senyawa aromatik ringan pada RAP yang mengalami penguapan atau teroksidasi. Senyawa aromatik ringan dari zat aditif/rejuvenile harus dapat menembus lapisan aspal lama dan berdifusi pada RAP. Kondisi ini diharapkan dapat memperbaharui aspal yang lama dan menua untuk menjadi bahan aspal yang layak untuk menjadi lapis perkerasan baru (Qiu dkk, 2013 dalam Nono, 2018).

Tabel 2. Sifat RAP untuk Daur Ulang

\begin{tabular}{|c|c|}
\hline Karakteristik & Persyaratan \\
\hline Kadar aspal dalam RAP, $\%$ & Min. 3,8 \\
\hline Penetrasi aspal RAP pada suhu $25^{\circ} \mathrm{C}, 100$ gr, 5 detik, 0,1 mm & Min. 20 \\
\hline Persentase agregat lolos ayakan $75 \mu \mathrm{m}$ (No. 200) & Maks. 5,0 \\
\hline Sumber: NAPA, 2015 dalam Nono, 2018 & \\
\hline
\end{tabular}

Berdasarkan pada 9 data dari hasil penelitian terdahulu terkait pemanfaatan RAP jalan nasional di Jawa Timur, diperoleh hasil bahwa kadar aspal dalam campuran berada dalam rentang 3,78-4,63\%. Persyaratan bahan daur ulang beraspal (RAP) hasil ekstraksi dan pemulihan sebesar 3,8\% (NAPA, 2015 dalam Nono, 2018). Dalam hal ini kadar aspal dalam RAP jalan nasional Jawa Timur memenuhi batasan minimum kadar aspal yang disyaratkan. Penetrasi sebesar 19-49, persyaratannya 60-70. Viskositas sebesar 1440-2300, persyaratannya $\geq 300$. Titik lembek dalam kisaran 55-65,5, persyaratan $\geq 48$. Daktililitas 11,5-24, persyaratannya $\geq 100$. Berat jenis 1,056-1,067. Karakteristik aspal RAP memenuhi persyaratan pada aspek viskositas dan titik lembek, sedangkan tidak memenuhi syarat pada aspek penetrasi dan daktilitas. Oleh karena itu perlu penambahan material lain yang ramah lingkungan, sehingga dapat mengantisipasi kelemahan yang terjadi (Widayanti dkk, 2017).

Viskositas tinggi dan penetrasi rendah mengakibatkan campuran bersifat plastis, yang ditunjukkan dengan indikator flow tinggi. Aspal keras dengan daktilitas yang rendah merupakan aspal dengan kohesi yang kurang baik. Pengujian untuk mengukur durabilitas aspal adalah penetrasi, titik lembek, kehilangan berat dan daktilitas. Penetrasi dan viskositas merupakan sifat aspal yang peka terhadap temperatur (Widayanti dkk, 2018a).

Aspek ekonomi pemanfaatan RAP ditinjau dari efisiensi biaya yang terjadi adalah penghematan untuk lapisan AC-WC sebesar 10-19\%, rata-rata sebesar 14,9\%. Penghematan untuk lapisan AC-BC sebesar 9-17\%, rata-rata sebesar 14\%. Penghematan untuk lapisan AC Base sebesar 19-21\%, rata-rata sebesar 20,4\% (Widayanti dkk, 2018b).

Berdasarkan ukuran agregat RAP, RAP dari jalan nasional di Provinsi Jawa Timur mempunyai kesesuaian digunakan sebagai lapisan AC-WC sebesar 82,3\%, AC-BC sebesar 68,7\% dan AC-Base sebesar 41,7\%. Lokasi pengambilan RAP asli akan sangat menentukan kesesuaian ukuran agregat RAP untuk ketiga lapisan AC. Penggunaan RAP perlu mempertimbangkan penggunaan zat aditif dan aspal baru disebabkan oleh adanya penuaan aspal akibat pembebanan kendaraan, faktor cuaca dan air yang disebabkan oleh hujan, drainase 
pada jalan serta faktor kelembaban udara. Diharapkan dengan penambahan aspal baru, zat aditif dan agregat yang baru dapat meningkatkan kinerja Asphalt Concrete yang dicampur dengan RAP (Widayanti dkk, 2019). Berikut ini standar sifat aditif dari beberapa sumber.

Tabel 3. Standar Sifat Zat Aditif

\begin{tabular}{|c|c|c|c|}
\hline Pengujian & Pusjatan (2019) & NAPA (2015) & ASTM (2010) \\
\hline Viskositas kinematis pada $60^{\circ} \mathrm{C}, \mathrm{cSt}$ & Maks. $1000 \mathrm{cSt}$ & $80-1000 \mathrm{cSt}$ & $50-50000 \mathrm{~mm}^{2} / \mathrm{s}$ \\
\hline Titik nyala, ${ }^{0} \mathrm{C}$ & Min. $232^{\circ} \mathrm{C}$ & Min. $250^{\circ} \mathrm{C}$ & Min. $219^{\circ} \mathrm{C}$ \\
\hline Berat jenis & Min. 0,90 & - & - \\
\hline Perubahan berat setelah TFOT (\%) & Maks. 1,5\% & Maks. 3\% & Maks. 3-4\% \\
\hline Rasio viskositas pada $60^{\circ} \mathrm{C}$ & Maks. 2 & Maks. 2 & Maks. 3 \\
\hline Sumber: Pusjatan, 2018 dalam Nono, 2018 & & & \\
\hline
\end{tabular}

\section{PENGUMPULAN DATA}

Pengumpulan data pada studi ini terdiri dari studi literatur dari penelitian terkait RAP dan penggunaan zat aditif pada RAP, mencakup:

- Studi literatur terkait pemanfaatan zat aditif pada lapisan perkerasan jalan dengan RAP.

- Pengumpulan zat aditif jenis NR.

- Pengujian dan analisis terhadap sifat aditif NR.

Berikut ini adalah tahapan pengujian material NR yang digunakan pada penelitian ini.

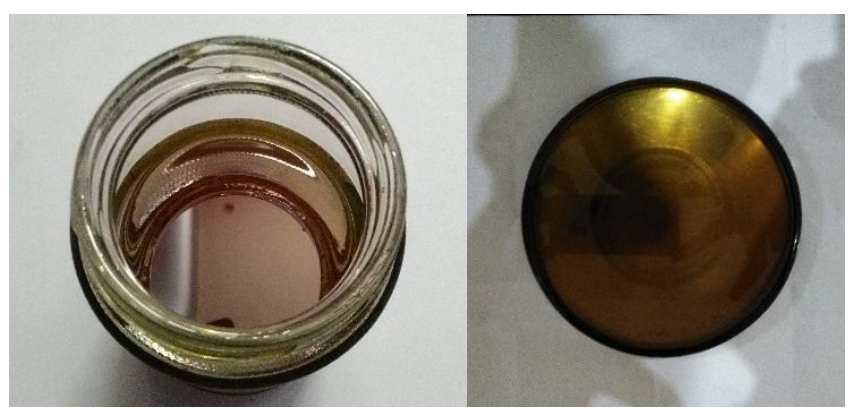

Gambar 1. Bentuk Fisik Zat Aditif NR

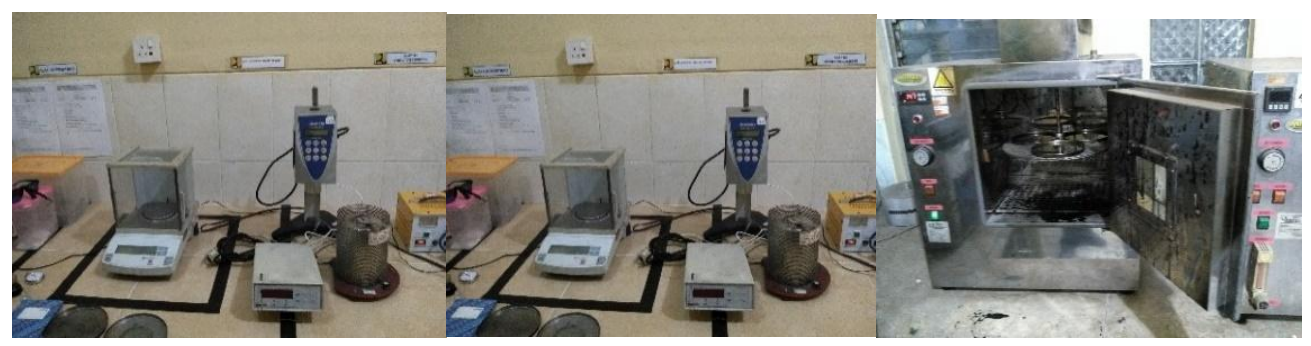

Gambar 2. Proses Pengujian Zat Aditif Kehilangan Berat TFOT dan RTFOT 
(e)ISSN 2615-1847 (p)ISSN 2615-1839

Jurnal Manajemen Aset Infrastruktur \& Fasilitas - Vol. 4, No. 1, Januari 2020

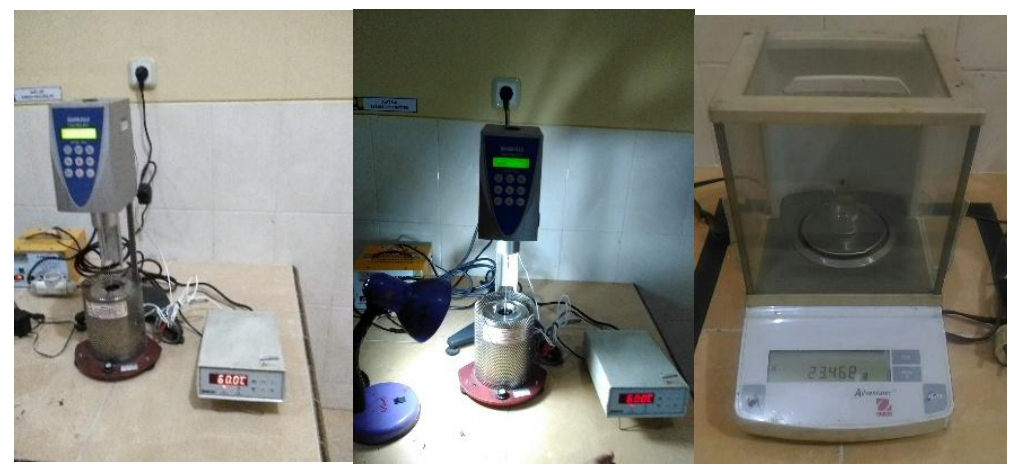

Gambar 3. Proses Pengujian Viskositas

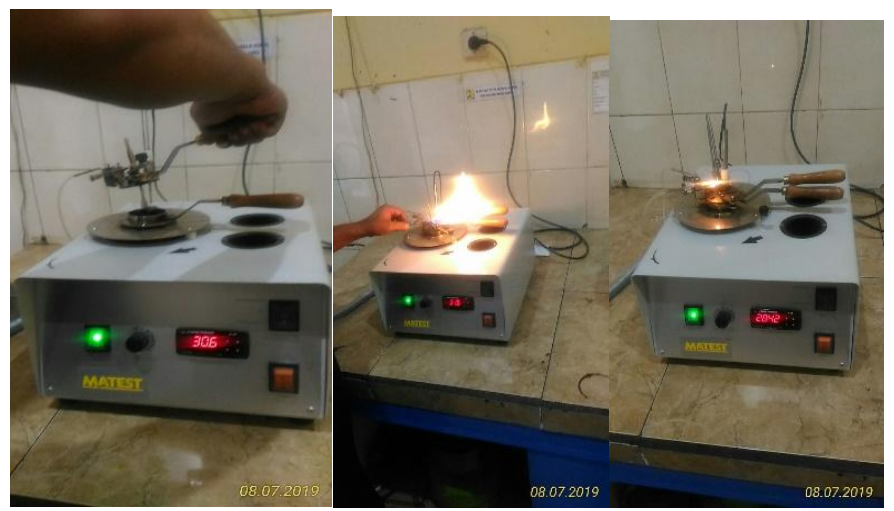

Gambar 4. Proses Pengujian Titik Nyala

\section{ANALISIS PENELITIAN}

Berdasarkan hasil analisis zat aditif NR dan zat aditif RAP yang berasal dari beberapa penelitian terdahulu, dipresentasikan pada Tabel 4 berikut ini. 
Tabel 4. Perbandingan Sifat Fisik dan Kimia Zat Aditif

\begin{tabular}{|c|c|c|c|c|c|c|c|c|c|c|}
\hline \multirow{2}{*}{$\frac{\text { Parameter }}{\text { Nama Zat Aditif }}$} & \multirow{2}{*}{$\begin{array}{c}\text { Widayanti, } 2019 \\
\text { NR }\end{array}$} & \multicolumn{3}{|c|}{ Nono, 2017} & \multicolumn{2}{|c|}{ Pradyumna, 2016} & \multicolumn{2}{|c|}{ Yang, 2016} & \multirow{2}{*}{$\begin{array}{c}\text { Cong, } 2016 \\
\text { RA }\end{array}$} & \multirow{2}{*}{$\begin{array}{c}\text { Shen, } 2007 \\
\text { Oil RAC } \\
\text { US }\end{array}$} \\
\hline & & $\begin{array}{l}\text { Minyak } \\
\text { Goreng }\end{array}$ & $\begin{array}{c}\text { Minyak } \\
\text { Pelumas }\end{array}$ & RejIRE & RA-1 & RA-2 & $\begin{array}{c}\text { RA } 1 \\
(75)\end{array}$ & $\begin{array}{l}\text { RA } 2 \\
(25)\end{array}$ & & \\
\hline Viskositas pada $25^{\circ} \mathrm{C}, \mathrm{cSt}$ & 739,958 & 103 & 165 & 276 & - & - & - & - & - & - \\
\hline Viskositas pada $60^{\circ} \mathrm{C}, \mathrm{cSt}$ & 232,558 & 28,6 & 34,9 & 39,1 & 41 & 58 & 59,96 & 14,78 & 1,72 & 200 \\
\hline Titik nyala, ${ }^{0} \mathrm{C}$ & 282 & 322 & 218 & 296 & - & - & - & - & 230 & 204 \\
\hline Saturasi ( $\%$ berat) & - & - & - & - & 4 & 5 & 16 & 23 & 15,6 & 28 \\
\hline Berat jenis & 0,946 & 0,921 & 0,874 & 0,996 & - & - & 1,034 & 1,015 & - & 0,980 \\
\hline Kehilangan berat (\%) RTFO-C $163^{\circ} \mathrm{C}$ & 0,079 & - & - & - & - & - & 1,89 & 1,98 & - & 4 \\
\hline Rasio viskositas RFT-C & 0,606 & - & - & - & - & - & 1,63 & 1,37 & 1,23 & 2,5 \\
\hline Aromatik $(\%)$ & - & - & - & - & 68 & 59 & - & - & 52,8 & - \\
\hline Resins $(\%)$ & - & - & - & - & 27 & 33 & - & - & 28,2 & - \\
\hline Asphaltenes (\%) & - & - & - & - & 1 & 3 & - & - & 3,4 & - \\
\hline Kompatibilitas & - & - & - & - & - & - & - & - & - & 0,5 \\
\hline Kompatibilitas kimia & - & - & - & - & - & - & - & - & - & 0,2 \\
\hline \multicolumn{11}{|l|}{ Keterangan: } \\
\hline \multicolumn{11}{|c|}{$\begin{array}{l}\text { Viskositas adalah ukuran yang menyatakan kekentalan dari suatu cairan atau fluida. Viskositas kinematis merupakan perbandingan antara viskositas } \\
\text { absolut cairan dengan densitas massa cairan. }\end{array}$} \\
\hline \multicolumn{11}{|c|}{ Titik nyala adalah titik temperatur aspal mulai menyala singkat. } \\
\hline \multicolumn{11}{|c|}{ Saturasi atau kejenuhan dari suatu zat. } \\
\hline \multicolumn{11}{|c|}{ Berat jenis adalah perbandingan relatif antara massa jenis zat dengan massa jenis air murni. } \\
\hline \multicolumn{11}{|c|}{ Rasio viskositas adalah perbandingan antara viskositas sisa dari RTFOT atau TFOT pada suhu $60^{\circ} \mathrm{C}$ dengan viskositas asli pada suhu $60^{\circ} \mathrm{C}$. } \\
\hline \multicolumn{11}{|c|}{ Aromatik adalah senyawa hidrokarbon dengan ikatan tunggal dan ikatan rangkap diantara atom-atom karbonnya. } \\
\hline \multicolumn{11}{|c|}{$\begin{array}{l}\text { Resins merupakan bagian dari maltenes, yang berupa cairan kental, mudah berubah karena pengaruh perubahan temperatur dan masa pelayanan jalan. } \\
\text { Resins berwarna kuning atau coklat tua, menghasilkan sifat adhesi aspal, mudah hilang atau berkurang selama masa pelayanan jalan. }\end{array}$} \\
\hline \multicolumn{11}{|c|}{ Asphaltenes adalah material pembentuk aspal yang tidak larut dalam n-heptane, terdiri dari senyawa hidrokarbon, berwarna hitam atau coklat tua. } \\
\hline Komnotibilitos odolob lemomnuon untul & senyesuaian. & & & & & & & & & \\
\hline
\end{tabular}


Berdasarkan pada Tabel 4 diperoleh gambaran sifat fisik dan kimia dari variasi bahan aditif yang berasal dari berbagai sumber. Nilai viskositas yang lebih besar menunjukkan material yang lebih kental daripada material yang lain. Titik nyala yang cukup tinggi menunjukkan material aman untuk digunakan, dan memenuhi kriteria yang distandarkan. Hasil pengujian terhadap zat aditif NR menunjukkan bahwa zat aditif tersebut memenuhi kriteria dari parameter pengujian ditinjau dari spesifikasi pada Pusjatan (2018), NAPA (2015), dan ASTM (2010), sehingga aman dan layak untuk digunakan dalam campuran RAP untuk lapisan perkerasan jalan.

Pemanfaatan RAP mempunyai kelemahan yaitu penetrasi rendah, daktilitas rendah dan viskositas yang terlalu tinggi mengakibatkan bahwa aspal hasil RAP bersifat kaku/getas. Hal ini diakibatkan oleh sifat aspal yang berubah akibat panas, pembebanan dan umur pelayanan jalan. Aspal menjadi kaku dan rapuh, dan kemungkinan daya adhesi terhadap partikel agregat akan berkurang. Proses pengerasan aspal disebabkan oleh adanya oksidasi, penguapan dan perubahan kimia. Reaksi kimia dapat mengubah resins menjadi asphaltenes, dan oils menjadi resins, yang mengakibatkan peningkatan viskositas aspal. Hal ini memerlukan penelitian lebih lanjut terkait perubahan sifat kimia aspal yang berasal dari RAP, karena penelitian sebelumnya masih berupa pengujian teknis terhadap parameter pengujian aspal dan belum meneliti lebih lanjut terkait komposisi kimia dari aspal hasil RAP serta pengaruh zat aditif terhadap sifat aspal hasil RAP.

\section{KESIMPULAN}

Berdasarkan hasil pengumpulan data, analisis dan pembahasan yang sudah dilakukan maka kesimpulan yang diperoleh adalah

- Zat aditif NR memenuhi kriteria sebagai zat aditif pada campuran perkerasan jalan.

- Zat aditif NR aman digunakan untuk campuran perkerasan jalan.

Berdasarkan pada hasil analisis dan kesimpulan di atas, maka saran yang dapat diberikan adalah :

- Perlu adanya penelitian yang lebih mendalam terkait dengan sifat kimia dari aspal RAP serta zat aditif.

- Perlu analisis lebih lanjut terkait pengaruh zat aditif terhadap sifat aspal.

- Perlu analisis lebih lanjut terkait aplikasi zat aditif pada perkerasan lentur jalan raya.

CATATAN. Penulisan artikel ini didukung dengan beberapa literatur yang bertujuan untuk memperoleh hasil analisis zat aditif untuk Reclaimed Asphalt Pavement pada lapisan Beton Aspal. Kami menyampaikan terima kasih yang mendalam kepada para peneliti yang karyanya menjadi rujukan dalam penulisan artikel ini. Kami juga menyampaikan terima kasih yang mendalam kepada pihak Pusjatan Bandung dan PT. KADI International Karawang atas segala bantuan, masukan dan saran yang sudah diberikan.

Makalah ini merupakan makalah terpilih dari SeMAIF \#1 2019 - Seminar Nasional Manajemen Aset Infrastruktur \& Fasilitas, yang diselenggarakan oleh FoMA-PT - Forum Manajemen Aset antar Perguruan Tinggi.

\section{DAFTAR PUSTAKA}

Cong, P., Zhang, Y., Liu, N. (2016). "Investigation of the Properties of Asphalt Mixtures Incorporating Reclaimed SBS Modified Asphalt Pavement”. Journal Construction and Building Materials 113, hal. 334-340.

Handayani, R. (2016). "Analisa Penggunaan Reclaimed Asphalt Pavement (RAP) sebagai Bahan Campuran Beraspal Panas Tipe Asphalt Concrete-Binder Course (ACBC) dengan Menggunakan Fly Ash (Studi Kasus Ruas Jalan Taman Waru)". Tesis Pasca Sarjana. Institut Teknologi Sepuluh Nopember. Surabaya.

Roberts, F.L., Kandhal, P.S., Brown, E.R., Lee, D.Y., Kennedy, T.W. (1996). Hot Mix Asphalt Materials Mixture Design and Construction. NAPA (National Asphalt Pavement Association) Education Foundation. Lanham, Maryland. 
Nono (2017). Campuran Beraspal Hemat Agregat dan Aspal. Cetakan Pertama Agustus 2017. Kementerian Pekerjaan Umum dan Perumahan Rakyat, Pusat Penelitian dan Pengembangan Jalan dan Jembatan. LIPI Press. Jakarta.

Nono (2018). Campuran Beraspal Panas Daur Ulang dengan Proporsi RAP Tinggi. Cetakan Pertama Desember 2018. Kementerian Pekerjaan Umum dan Perumahan Rakyat, Badan Penelitian dan Pengembangan. Pusat Penelitian dan Pengembangan Jalan dan Jembatan. Bandung.

Pradyumna, T Anil. Mittal, Abhishek, Jain, P.K. (2013). "Characterization of Reclaimed Asphalt Pavement (RAP) for Use in Bituminous Road Construction”. Procedia-Social and Behavioral Sciences 104, hal. 1149-1157.

Shen, J., Amirkhanian, S., Aune, J.M. (2007). "Effects of Rejuvenator Agents of Superpave Mixtures Containing Reclaimed Asphalt Pavement". Journal of Materials in Civil Engineering, Volume 19, No. 5, May 1, 2007, ASCE, ISSN 0899-1561/2007/5-376-384.

Sukirman, S. (1995). Perkerasan Lentur Jalan Raya. Penerbit Nova. Bandung.

Sukirman, S. (2003). Beton Aspal Campuran Panas. Penerbit Granit. Jakarta.

Suprayitno, H. \& Soemitro, R.A.A. (2018). "Preliminary Reflexion on Basic Principle of Infrastructure Asset Management". Jurnal Manajemen Aset Infrastruktur \& Fasilitas, Vol. 2, No. 1, Maret 2018, Hal. : 1-10.

TRB (2011). A Manual for Design of Hot Mix Asphalt with Commentary. NCHRP Report 673. National Cooperative Highway Research Program. Transportation Research Board. Washington DC.

Widayanti, A., Soemitro, R.A.A., Ekaputri, J.E., Suprayitno, H. (2017). "Karakteristik Material Pembentuk Reclaimed Asphalt dari Jalan Nasional di Provinsi Jawa Timur". Jurnal Manajemen Aset Infrastruktur dan Fasilitas. Volume 1, No. 1, Desember 2017.

Widayanti, A., Soemitro, R.A.A., Ekaputri, J. E., Suprayitno, H. (2018a). "Kinerja Campuran Aspal Beton dengan Reclaimed Asphalt Pavement dari Jalan Nasional di Provinsi Jawa Timur". Jurnal Manajemen Aset Infrastruktur dan Fasilitas, Volume 2, No. 1, Maret 2018.

Widayanti, A., Soemitro, R.A.A., Ekaputri, J. E., Suprayitno, H. (2018b). "Tinjauan Aspek Ekonomi Pemanfaatan Reclaimed Asphalt Pavement dari Jalan Nasional di Provinsi Jawa Timur". Jurnal Manajemen Aset Infrastruktur dan Fasilitas, Volume 2, Suplemen 2, Desember 2018.

Widayanti, A., Soemitro, R.A.A., Ekaputri, J.E., Suprayitno, H. (2019). "Gradation Analysis of Reclaimed Asphalt Pavement from National Road as Asphalt Concrete Layer”. Journal of Infrastructure Asset Management. Volume 1, No. 1, March 2019.

Yang, S.H., Lee, L.C. (2016). "Characterizing the Chemical and Rheological Properties of Severely Aged Reclaimed Asphalt Pavement Materials with High Recycling Rate". Journal Construction and Building Materials 111, hal. 139-146. 


\section{(e)ISSN 2615-1847 (p)ISSN 2615-1839}

Jurnal Manajemen Aset Infrastruktur \& Fasilitas - Vol. 4, No. 1, Januari 2020 